\title{
Fuzzy Gravity Approach for Determinants of Exports
}

\author{
Submitted 21/07/19, $1^{\text {st }}$ revision 25/08/19, $2^{\text {nd }}$ revision 09/10/19, accepted 03/1 1/19
}

\begin{abstract}
Değirmenci N. ${ }^{1}$, Yakıcı Ayan T. ${ }^{2}$
Abstract:

Purpose: The present study proposes the fuzzy gravity model approach to examine the main factors that affect the export volume of Turkey and whether the European Union Customs Union (EUCU) membership affected the export of it.

Design/Methodology/Approach: A fuzzy approach was developed for the gravity model by using these variables. The dependent variable was the export volume of Turkey to 204 countries throughout the whole world, and the explanatory variables were the gross domestic product $(G D P)$ of the countries that are subject to export and their distances to Turkey $\left(d_{i j}\right)$, populations, whether the seaway transport was possible, and the membership to the EUCU. The last two items were added as dummy variables in the model.

Findings: The results showed that gross domestic product (GDP) of the country which Turkey exports to, its being a member of the EUCU, and its population affected the export volume of Turkey positively. However, the distance of the target country to Turkey had a negative effect. The coefficient of distance variable was found to be negative fuzzy and ones of the seaway was fully fuzzy. However, when seaway variable was taken together with distance, it was positive fuzzy, which showed the positive effect of the opportunity of transportation by sea in long distances on export volume.

Practical Implications: It is thought that the policies to be established based on these findings will be beneficial in improving the country's exports. Other available fuzzy regression approaches may be tried in future studies to obtain a fuzzy model. In addition, the import or foreign trade structure of Turkey may be dealt with the same approach.

Originality/Value: In this study the fuzzy gravity model approach was used as a novelty, which was different from the methods in the literature, because the gravity model is criticized sometimes that its theoretical basis is weak and the relations between dependent variables and explanatory variables are not adequately clear.
\end{abstract}

Keywords: Gravity model, Fuzzy logic, Foreign trade, Exports.

JEL codes: F14, C4, C65.

\footnotetext{
${ }^{1}$ Department of International Trade and Logistic, Recep Tayyip Erdoğan University, Rize, Turkey,nurdan.degirmenci@erdogan.edu.tr ${ }^{2}$ Department of Econometrics, Karadeniz Technical University, Trabzon, Turkey, ayan@ktu.edu.tr
} 


\section{Introduction}

As a complementary element of economic growth and development, exports have vital importance for the economic integration of Turkey with the outside world. Export salso affect the country's production and employment opportunities at a significant level. For this reason, the direction and degree of impact of factors affecting exports should be well defined when taking various precautions and developing policies to increase exports.

Turkey was included in the European Union Customs Union (EUCU) in 1996. The purpose of the formation of the EUCU was to ensure that member countries have a sustainable trade volume by applying one common customs tariff with a foreign trade agreement among the members. In recent years, it was brought into the agenda that the share of the member countries in Turkey's foreign trade decreased significantly, and it was also claimed that the actual effect of EUCU on Turkey's foreign trade was not on the export but on import. For this reason, in this study, especially export volume was dealt with instead of foreign trade to examine the reality of this argument.

The purpose of this study was to determine the main factors affecting Turkey's exports as well as to reveal whether the membership of the EUCU affected its export volume. For this purpose, the fuzzy gravity model approach was used as a novelty, which was different from the methods in the literature. In this respect, firstly, the model that was built with the traditional gravity model approach was analyzed. Then, the fuzzy gravity model was introduced, applied, and empirical findings were obtained. The study was concluded with the interpretation of the findings.

\section{Literature Review}

The analysis of trade flows among countries attracts a significant amount of attention in the literature. Especially, the gravity model approach has made contributions to research on this subject in empirical terms. The gravity model was inspired by the famous gravity formula in physics, and was first used by Isard (1954), and then by Tinbergen (1962), Pöyhönen (1963), and Linnemann (1966) to analyse international trade. Some of the studies that were conducted with the gravity model are summarized below.

Aitken (1973) examined the impact of the European Economic Community (EEC) and the European Free Trade Association (EFTA) on the trade of European countries using the augmented gravity model for the period 1951-1967. The findings of this study indicated that being a member of the communities affect considerably the trade of the countries.

Chan-Hyun (2001) analysed the commercial structure of Korea based on the gravity model, and proposed probable ways to expand the trade of the country by determining the important factors that affected the bilateral commercial activities of Korea. As a 
result of the study, they reported that the gross domestic product (GDP) and GDP per capita of the commercial partner of the country affected the foreign trade volume positively, and the distance between them affected it negatively. Furthermore, the increase in the commercial integration among countries, and APEC (Asian-Pacific Economic Cooperation Organization) membership of the commercial partner country also had a positive effect.

Neyaptı et al. (2003) estimated the import and export equations of the countries by using panel data in their study. They found that EUCU affected both imports and exports at a positive and significant level during the 1980-2001 period. When they included crisis periods in their analysis, again, their findings showed that import and export were affected positively and significantly by the EUCU.

Nowak-Lehmann and Martinez-Zarzoso (2003) used the gravity model with the data from 1988-1996 for 20 countries to examine the trade between Southern Common Market (MERCOSUR) and the European Union. The study showed that infrastructure, income differences and exchange rate were important as well as standard gravity model variables.

Rahman (2003) analysed the trade of Bangladesh by using the panel gravity model. As a result, it was determined that Bangladesh's foreign trade was affected positively by economic size, GNP per capita and trade opening of the country with which it carried out its foreign trade and it was negatively affected by transportation costs and was not affected by exchange rates.

Sohn (2005) used the gravity model to analyse the trade flows between South Korea and its trading partners. According to the findings, South Korea's trade structure followed a Heckscher-Ohlin Model, and the Asia-Pacific trade network had a significant and positive effect on Korea's trade volume.

Kristjánsdóttir (2005) conducted a study on Iceland by using the panel gravity model, and determined that the country factors and distance were effective on trade. Rahman et al. (2006) explored the trade potentials of SAFTA member countries with an extended gravity model; and found that increasing trade volume also increased the potential for high economic growth.

Antonucci and Manzocch (2006), using the gravity model with 1967-2001 data, found that a special trade relationship between the European Union and Turkey doesn't exist. Simwaka (2006) investigated the factors that affected the commercial flows of Malawi's main trade partners taking advantage of the panel gravity model. As a result of the study, they concluded that economic magnitude, geographical distance, and exchange rate fluctuations were effective on foreign trade volume. The effect of neighbourhood and regional economic agreements was not significant. NowakLehmann et al. (2007) used the general gravity model to examine the effects of the EUCU membership of Turkey on trade flows to the EU, and they concluded that the 
export to EU increased. Khan et al. (2013) investigated the commercial activities between Pakistan and its major trading partners with the gravity model by using the panel dataset. They showed that the GDP and the GDP per capita affected the trade volume positively, and the geographical distance and cultural similarities negatively.

Elshenawy et al. (2014) used the gravity model to investigate the factors, which determined the export of Egypt. They determined that the GDP of countries, the population of the importing country, regional trade agreements, and being bordering countries affected Egypt's exports positively. Suresh (2014) used the panel gravity model, and examined the trade of India with its southern and northern neighbours. As a result, he argued that trading with countries in southern India would increase its export.

In his study on the general trade structure of Nepal, Prasai (2014) used the panel gravity model and argued that Nepal had to improve its trade by making commercial agreements with China and India with which Nepal had geographical proximity. Waheed and Abbas (2015) used the panel gravity model, and determined that foreign exchange reserves of the commercial partners of Bahrain had a significant and positive effect on Bahrain's export volume. Wang and Badman (2016) showed that the distance variable had a negative effect, and economic size had a positive effect on Peru's trade. Abidin and Haseeb (2018) examined the effects of various macroeconomic indicators, the number of Islamic banks, zakat collection rate and inter-country distance on bilateral trade between Malaysia and Gulf Cooperation Council (GCC) countries. In the study using the 1990-2017 panel time series data and the gravity model, variables such as real exchange rate, inflation and distance were negatively significant, while variables such as GDP, the number of Islamic banks and zakat collection were found to be positive.

Sheikh et al. (2018), using 2003-2014 data, solved the gravity model with ordinary least squares (OLS) to analyse the institutional determinants of bilateral trade for Pakistan and the effect of homogeneity with Economic Cooperation Organisation (ECO) countries. According to the findings, institutional quality and homogeneity have a significant effect on bilateral trade flows. Tang (2018) investigated the relationship between export sophistication and foreign trade using an augmented gravity model approach. The results obtained for Mauritus from the 1995-2013 annual data showed that sophistication plays a positive and significant role in sustaining exports. Mauritus' exports have also been positively related to preferential trade agreements, colonial and island links, and the income of the trading partner country.

Osabuohien et al. (2019) examined the functioning of regional trade agreements by identifying trade barriers affecting the development of bilateral trade between Economic Community of West African countries (ECOWAS). They then estimated the determinants of bilateral trade in the region with the augmented gravity model. As a result, it was found that commercial complementarity, multilateral commercial 
resistance and economic integration agreements were positive and important factors in addition to other factors.

\section{Methodology}

In this study, the dependent variable was the export volume of Turkey to 204 countries throughout the whole world, and the explanatory variables were the gross domestic products (GDP) of the countries that are subject to export and their distances to Turkey $\left(\mathrm{d}_{\mathrm{ij}}\right)$, populations, whether the seaway transport was possible, and the membership to the EUCU. The last two items were added as the dummy variables in the model. The 2016 data on the variables were obtained from the World Bank databank website.

A fuzzy approach was developed for the gravity model by using these variables. The Gravity model is a model that was inspired by the famous gravity formula in physics, and was first used by Isard (1954), Tinbergen (1962), Pöyhönen (1963) and Linnemann (1966) to analyse international trade volume. The gravity model, which might be converted into a linear regression model because of its structure, is subject to criticism sometimes that its theoretical basis is weak. The relations between dependent variables and explanatory variables are not adequately clear. For this reason, in this study, it was decided that it would be better to approach the gravity model with fuzzy logic.

Model (1) given below is the version of the famous gravity model in physics adapted to international trade. It is accepted that the foreign trade volume between two countries is directly proportional to the GDP of these countries, and inversely proportional to the physical distance between them.

${\text { Foreign } \text { Trade }_{i j}}_{i j} \mathrm{c} * \frac{\mathrm{GDP}_{\mathrm{i}} * \mathrm{GDP}_{\mathrm{j}}}{\text { Distance }_{\mathrm{ij}}^{2}}$

The export volume of Turkey was modelled as follows in the present study by making use of the general model given above.

$\operatorname{lnexp}_{\mathrm{j}}=\beta_{0}+\beta_{1} * \operatorname{LnGDP}_{\mathrm{j}}+\beta_{2} * \operatorname{Lndis}_{\mathrm{ij}}+\beta_{3} * \operatorname{Lnpop}_{\mathrm{j}}+\beta_{4} * \mathrm{CU}_{\mathrm{j}}+\beta_{5}$ seaway $_{\mathrm{j}}$

where,

$\exp _{\mathrm{j}}$ : It shows the export of Turkey to the the country $(j)$;

$\operatorname{dis}_{\mathrm{ij}}$ : The distance between Turkey $(i)$ and the country $(j)$ Turkey exports;

GDP: The GDP of the country $(j)$ to which Turkey exports, GDP of Turkey is constant, it is not included in the model as a variable;

pop $_{j}$ : The population of the $\operatorname{country}(j)$ to which Turkey exports;

$\mathrm{CU}_{\mathrm{j}}$ : It is " 1 " if country $\mathrm{j}$ is member to the CU else it is " 0 ". The purpose of adding the variable to the model is to determine whether the partnership in the CU affected the export or not; 
seaway $\mathrm{j}$ : For country $\mathrm{j}$ if transport is possible through seaway it is "2", else it is " 1 ". The purpose of adding this variable is to determine whether seaway transport possibility causes any changes in the export volume of Turkey through. The Regression Model (3) below was obtained as a result of solving the Model (2) by EKK.

Lnexp $=-7.14+0.399$ LnGDP -0.412 Lndis +0.387 Lnpop +1.681 CU +1.087 seaway

Table 1. Gravity Equation (crisp).

\begin{tabular}{|l|l|l|}
\hline Explanatory Variables & Log. Exp. & P-value \\
\hline Constant & -7.140 & 0.000 \\
\hline LnGDP & 0.399 & 0.000 \\
\hline Lndis & -0.12 & 0.000 \\
\hline Lnpop & 0.387 & 0.000 \\
\hline CU & 1.681 & 0.000 \\
\hline seaway & 1.087 & 0.001 \\
\hline F & 49.793 & 0.000 \\
\hline R Square & 0.780 & \\
\hline Adjusted R Square $\mathbf{( R}^{\mathbf{2}}$ & 0.609 & \\
\hline
\end{tabular}

The regression coefficients to be significant, and $\mathrm{R}^{2}$ to be high are the most important conditions that must be present before the fuzzy regression phase. Table 1 shows that these conditions were met. A fuzzy regression model was developed to get fuzzy the gravity model (2) summarized above. Then, the model was solved by the method of Tanaka, Uejima and Asai, (1982), which converted the model into linear programming. This method allows us to obtain fuzzy coefficients.

Fuzzy regression analysis may be used where the model structure between dependent and independent variables is not known (or is uncertain) or when the observation values are not certain. Linear programming, on the other hand, is a mathematical method, and provides reliable and easily-interpreted results because it is not based on rigorous assumptions unlike statistical methods. The fuzzy regression equation can be expressed in the simplest form as follows, " $"$ " representing fuzziness:

$\hat{\mathrm{y}}=\widetilde{\mathrm{A}}_{0}+\widetilde{\mathrm{A}}_{1} \mathrm{X}_{1}$

The fuzziness here might stem from the data or from the relations between dependent and independent variables. Fuzzy coefficients are shown as $\tilde{A}_{i}=\left(c_{i}, s_{i}\right)$. Here $c_{i}$ and $\mathrm{s}_{\mathrm{i}}$ represent the center and the spread of the fuzzy symmetric coefficient respectively as in Figure 1.

The fuzzy regression equation given above (4) may be converted into the linear programming model given below. In this model, total fuzziness of the regression coefficients is minimized. 
Figure 1. Triangular Fuzzy Number

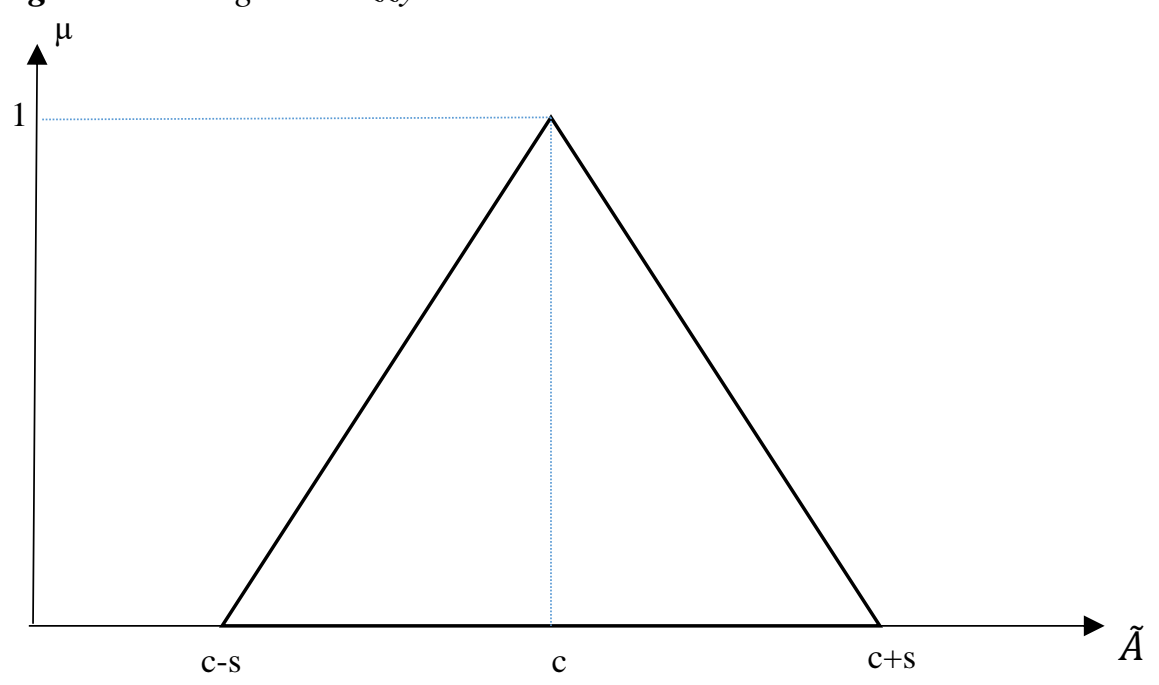

$\mathrm{Z}_{\min }=\mathrm{n} \cdot \mathrm{s}_{0}+\sum_{\mathrm{j}=1}^{\mathrm{n}}\left(\mathrm{s}_{\mathrm{j}} \sum_{\mathrm{i}=1}^{\mathrm{m}}\left|\mathrm{x}_{\mathrm{ij}}\right|\right)$

$\sum_{j=0}^{m} c_{j} x_{i j}+(1-H) \sum_{j=0}^{m} s_{j}\left|x_{i j}\right| \geq y_{i}+(1-H) e_{i} \quad i=1$,

$\sum_{j=0}^{m} c_{j} x_{i j}-(1-H) \sum_{j=0}^{m} s_{j}\left|x_{i j}\right| \leq y_{i}-(1-H) e_{i} \quad i=1, \ldots ., n$

In Model (5-7), " $m$ " refers to the number of variables, " $\mathrm{n}$ " refers to the number of observations, in other words, the number of countries in this study. In addition, " $\mathrm{H}$ ", which is measure of goodness of fit for fuzzy linear regression method, is called the degree of belief and is formulated as follows.

$\mathrm{H}=1-\frac{\left|\mathrm{c}_{\mathrm{i}}-\mathrm{y}_{\mathrm{i}}\right|}{\mathrm{s}_{\mathrm{i}}}$

In other words, $\mathrm{H}$ is the degree of membership of an observed dependent variable to its estimated fuzzy dependent variable. Although the recommended value for " $\mathrm{H}$ " is 0.50 ; it is the most appropriate approach to decide by experimenting with different values by the trial and error technique. As a result of the experiments with various degrees of fuzziness, the model with fuzzy coefficients, which has the lowest error, is given in the empirical findings section.

\section{Empirical Findings}

To obtain a more flexible and realistic model than the crisp regression model (3), the following model (9) was obtained by using the fuzzy regression approach of Tanaka et al. (1982). 
lnexp $=(-37.17 ; 22.89)+0.399 \operatorname{LnGDP}+(-0.687 ;-0.1365)$ Lndis + 0.387 Lnpop $+1.681 \mathrm{CU}+(-11.7827 ; 13.9567)$ seaway

According to the findings obtained from the model:

$>$ The GDP and population of the country to which the export is carried out have a positive effect on the export volume, while the distance between two countries affects it negatively.

$>$ In addition, it was determined that Turkey exported more to its partners in the EUCU when compared to other countries.

$>$ The coefficients of "distance" and "seaway" variable were fuzzy. However, although the distance variable was fuzzy in terms of the degree of impact, but not in terms of its direction, the seaway variable was fuzzy in both respects. For this reason, it can't be defined based on this finding exactly how possibility of exporting to a country by seaway affects its export amount.

$>$ In addition, when interactions between variables were controlled, it was determined that the "seaway" and "distance" variables were significant together in a positive way. This finding shows that transportation by sea has an effect of increasing exports for especially long distances.

\section{Conclusion}

After the gravity model proved to have a high explanatory power in various empirical studies, researches on this subject increased rapidly. In many studies, it has been tried to expand the model by adding different variables such as common language, transportation costs, free trade agreements, cultural and political factors, border sharing and monetary unions to the gravity model equation.

The fuzzy logic approach is frequently preferred in empirical studies conducted in almost every field particularly in recent years. The reason for this is because the approach considers the uncertainty and variability of real life. In this study, it was considered that approaching the gravity model with a fuzzy logic would make a significant contribution to the literature, and it was seen that it did such a contribution. In this respect, the export volume of Turkey was examined with a fuzzy gravity model approach, and more flexible and realistic findings were obtained compared to the classical approach.

According to the findings that were obtained from the study, the effects of the distance among countries and seaway transport on export volume were fuzzy; however, the effects of other variables were crisp. Although the GDP, population and CU membership among these variables affected the export volume in a positive way, the distance between countries affected the export volume in a negative way.

In many studies, it was reported that maritime transport had an increasing effect on export volume because of low costs and large cargo amounts carried simultaneously. However, in this study, it was observed that maritime transport had sometimes 
negative and sometimes positive effects on export volume. Because of factors like the duration of travel, the cost value, international and bureaucratic agreements, and the type of materials transported, seaway transport may have negative or positive effects on export volume.

It is thought that the policies to be established based on these findings will be beneficial in improving the country's exports. Approaches which are alternative to Tanaka et al. (1982) to obtain a fuzzy model are available. These methods may be tried in future studies. In addition, the import or foreign trade structure of Turkey may be dealt with the same approach.

\section{References:}

Abidin, I.S.Z., Haseeb, M. 2018. Malaysia-GCC Bilateral Trade, Macroeconomic Indicators and Islamic Finance Linkages. A Gravity Model Approach. Academy of Accounting and Financial Studies Journal, 22, 1-7.

Aitken, N.D. 1973. The effect of EEC and EFTA on European trade. A Temporal Crosssection Analysis. American Economic Review, 63(12), 881-892.

Antonucci, D., Manzocchi, S. 2006. Does Turkey have a Special Trade Relation with the EU? A gravity Model Approach. Economic Systems, (30), 157-169.

Chan-Hyun, S. 2001. A Gravity Model Analysis of Korea's Trade Patterns and the Effects of a Regional Trading Arrangement. Korea Institute for International Economic Policy, Working paper, No. 9.

Danzinger, F.N.L., Herzer, D., Martinez-Zarzoso, I., Vollmer, S. 2007. The Impact of a Customs Union between Turkey and the EU on Turkey's Exports to the EU. JCMS, Working paper, No. 483.

Elshenawy, M.A., Shen, H., Ahmed, R.A. 2014. The Factors Affecting Egypt's Exports. Evidence from the Gravity Model Analysis. Open Journal of Social Sciences, 2, 138-148.

Isard, W. 1954. Location Theory and Trade Theory. Short-Run Analysis. The Quarterly Journal of Economics, 68(2), 305-320.

Khan, S., Haq, I., Khan, D. 2013. An Empirical Analysis of Pakistan's Bilateral Trade. A gravity model approach. The Romanian Economic Journal, 16(48),103-120.

Kristjánsdóttir, H. 2005. A Gravity Model for Exports from Iceland. Centre for Applied Microeconometrics (CAM), 14, Available at http.//www.econ.ku.dk/cam/wp0910/wp0406/2005-14.pdf.

Linnemann, H. 1966. An Econometric Study of International Trade Flows. North Holland Press, Amsterdam.

Martinez-Zarzoso, I., Nowak-Lehmann, F. 2003. Augmented Gravity Model. An Empirical Application to Mercosur- European Union Trade Flows. Journal of Applied Economics, (6), 291-316.

Neyaptı, B., Taşkın, F., Üngör, M. 2003. Has European Customs Union Agreement Really Affected Turkey's Trade. Applied Economics, 39, 2121-2132.

Osabuohien, E., Efobi, U.R.. Odebiyi, J.T., Fayomi, O.O., Salami, A.O. 2019. Bilateral Trade Performance in West Africa. A Gravity Model Estimation. African Development Review, 31(1), 1-14.

Pöyhönen, P. 1963. A Tentative Model for the Volume of Trade between Countries. Weltwirtschaftliches Archiv, 90, 93-99. 
Prasai, P.L. 2014. Foreign trade pattern of Nepal. Gravity Model Approach. NRB Working Paper, No. 21.

Rahman, M., Shadat, W.B., Das, N.C. 2006. Trade Potential in SAFTA. An Application of Augmented Gravity Model. Centre for Policy Dialogue Occasional Paper Series, No. 61.

Rahman, M.M. 2003. A panel data analysis of Bangladesh's trade. The gravity model approach. Available at https.//www.etsg.org/ETSG2003/papers/rahman.pdf.

Sheikh, M.R., Chaudhry, I.S., Gul, N., Akhtar, M.H. 2018. Institutional Determinants of Bilateral Trade Flows. A Panel Data Analysis. Review of Economics and Development Studies, 4(2), 247-260.

Simwaka, K. 2006. Dynamics of Malawi's Trade Flows. A Gravity Model Approach. MPRA Working paper, No. 1122, available at https.//mpra.ub.uni-muenchen.de/1122/1/.

Sohn, C.H. 2005. Does the gravity model explain South Korea's Trade Flows? The Japanese Economic Review, 56(4), 417-430.

Suresh, K.G., Aswal, N. 2014. Determinants of India's Manufactured Exports to South and North. A Gravity Model Analysis. International Journal of Economics and Financial Issues, 4(1), 144-151.

Tanaka, H., Uejima, S., Asai, K. 1982. Linear Regression Analysis With Fuzzy Model. IEEE Transactions on Systems Man and Cybernetics, 12, 903-907.

Tang, V.T. 2018. Export Sophistication and Bilateral Trade in Mauritius. An Extended Gravity Model Approach. Springer International Publishing.

Tinbergen, J. 1962. Shaping the World Economy. Suggestions for an International Economic Policy, New York.

Wang, X., Badman, R.P. 2016. A Multifaceted Panel Data Gravity Model Analysis of Peru's Foreign Trade. Turkish Economic Review, 3(4), 562-577. 